\title{
EVALUASI PENGGUNAAN ANTIBIOTIKA TERHADAP PASIEN PNEUMONIA KOMUNITI DI RUMAH SAKIT IBNU SINA MAKASSAR
}

\author{
Dwi Anggara Putri Usman, Hendra Herman, Andi Emelda
}

Fakultas Farmasi Universitas Muslim Indonesia

Email : noncee2307@gmail.com.

\begin{abstract}
Pneumonia is an infectious disease that causes acute inflammation of the lung parenchyma. The purpose of this study was to compare the use of antibiotics and the appropriateness of antibiotics use in between Community acquired pneumonia patients include accuracy, appropriateness and administration duration of antibiotics compared with governance of community aquired pneumonia treatment Infectious Diseases Society Of America (IDSA) and World Health Organization (WHO). This study was retrospective descriptive survey with sampling technique that was purposive sampling. The results showed that the type of antibiotic used was ampicillin, ceftriaxone, ciprofloxacin, Cefepime, pentohydrate ceftazidime, cefotaxime, Cefadroxil, cefditoren pivoxil, azitromicin, meropenem, gentamicin and levofloxacin. The accuracy of antibiotics to community lbnu Sina hospital based management of IDSA and the WHO as many as 31(62.0\%) patients who appropriate and $18(36.0 \%)$ patients inappropriately. The accuracy of dose antibiotics in community acquired pneumonia patients Ibnu Sina hospital based management of IDSA and the WHO as many as 31 (62.0\%) patients who appropriate and 18(36.0\%) patients inappropriately. The duration of antibiotics in community acquired pneumonia patients Ibnu Sina hospital based management of IDSA and the WHO as many as 29 (58.0\%) patients who appropriate and 20 (40.0\%) patients inappropriately
\end{abstract}

Key Word : Evaluation, Antibiotics, Pneumonia, Ibnu Sina Hospital

\section{PENDAHULUAN}

Menurut World Health

Organization/WHO (2010) pneumonia merupakan salah satu penyebab kematian di seluruh dunia. Setiap tahun pneumonia membunuh sekitar 1,6 juta anak balita atau sekitar 14\% dari seluruh kematian balita di seluruh dunia. Angka ini lebih tinggi dibanding dari kematian akibat HIV/AIDS sebanyak $2 \%$, malaria $8 \%$ dan campak $1 \%$.

Pneumonia perlu mendapat perhatian, demikian pula dengan penggunaan antibiotika untuk pengobatannya karena beberapa penelitian menunjukkan bahwa antibiotik sering diberikan pada pasien. Pemilihan dan penggunaan terapi antibiotika yang tepat dan rasional 
Evaluasi Penggunaan Antibiotika Terhadap Pasien Pneumonia Komuniti Di Rumah Sakit Ibnu Sina Makassar

akan menentukan keberhasilan pengobatan untuk menghindari terjadinya resistensi bakteri. Pemberian antibiotik yang tidak memenuhi dosis regimen dapat meningkatkan resistensi antibiotik. Jika resistensi antibiotik tidak terdeteksi dan tetap bersifat patogen maka akan terjadi penyakit yang merupakan ulangan dan menjadi sulit disembuhkan (Ambarwati, 2011).

Tingginya angka resistensi terhadap antibiotik dari tahun ke tahun menimbulkan kekhawatiran global akan penyakit-penyakit infeksi yang mematikan. Salah satu penyebab resistensi antibiotik adalah cara pemberian dan penggunaan obat yang irrasional ini dapat berakibat berkurangnya manfaat obat bahkan manfaatnya hilang, serta kemungkinan beresiko munculnya efek samping dan peningkatan biaya obat. Oleh karena itu pemberian antibiotik sebaiknya sesuai dengan indikasi. Selain itu penggunaan antibiotik terutama pada anak-anak dan bayi juga harus mempertimbangkan efek samping pada sistem tubuh dan fungsi organ yang masih belum berkembang sempurna (Ambarwati, 2011).

Pemberian antibiotik yang tidak rasional akan mengakibatkan resistensi antibiotik. Berdasarkan hal ini dilakukan penelitian untuk mengevaluasi penggunaan antibiotik pada pasien pneumonia komunitas di rawat inap Rumah Sakit Ibnu Sina Makassar.

\section{METODE PENELITIAN}

\section{Metode Kerja}

Penelitian ini dilakukan secara deskriptif pada pasien dengan diagnosis pneumonia komuniti yang menjalani rawat inap di RS. Ibnu Sina Makassar selama bulan Januari sampai Desember 2013 dengan penelusuran secara retrospektif dan dibandingkan dengan tata laksana pengobatan pneumonia komuniti Infectious Diseases Society of America dan World Health Organization.

\section{Prosedur Kerja}

\section{Tahap persiapan}

Proses persiapan yang dilakukan sebelum pengambilan data adalah :

a. Pembuatan proposal

b. Pengurusan surat perijinan untuk melakukan pengambilan data

\section{Tahap pengambilan data}

Proses penelusuran data dimulai dari observasi (mendata jumlah rekam medis pasien yang menderita pneumonia komuniti di ruang rekam medis RS. Ibnu Sina Makassar. Lalu dilakukan pengambilan 
Evaluasi Penggunaan Antibiotika Terhadap Pasien Pneumonia Komuniti Di Rumah Sakit Ibnu Sina Makassar

data dengan langkah- langkah sebagai berikut:

a. Diambil data dari rekam medis pada pasien menderita pneumonia komuniti selama bulan Januari sampai Desember 2013.

b. Dari rekam medis pasien didapatkan data nama, jenis kelamin, umur jenis obat yang digunakan, dosis dan lama pemberian obat.

\section{Tahap pengolahan data}

Data yang diperoleh dari tahap sebelumnya dianalisis secara statistik, dengan cara membandingkan data hasil analisis dengan tata laksana pengobatan pneumonia komuniti Infectious Diseases Society of America dan World Health Organization.

\section{Analisis Data}

Evaluasi ketepatan penggunaan obat antibiotik dilakukan secara teoritis berdasarkan studi literatur. Analisis data menggunakan metode deskriptif yang menggambarkan penggunaan antibiotik dan uji t.test digunakan untuk membandingkan penggunaan antibiotik di RS. Ibnu Sina Makassar dengan tata laksana pengobatan pneumonia komuniti Infectious Diseases Society of America dan World Health Organization.

\section{HASIL PENELITIAN}

\section{Distribusi pasien berdasarkan kategori pasien.}

Pasien pneumonia komuniti dengan penggunaan antibiotika di RS. Ibnu Sina Makassar berdasarkan kategori pasien dapat dilihat pada tabel 1 sebagai berikut :

\section{Tabel 1. Kategori pasien pneumonia komuniti}

\begin{tabular}{clcc}
\hline No & \multicolumn{1}{c}{ Kriteria } & Jumlah (\%) & Rata-Rata (SD) \\
\hline 1 & Jumlah Pasien & $49(98)$ & \\
\hline \multirow{2}{*}{2} & Jenis Kelamin & & $1.42(.499)$ \\
& Jumlah Pasien Laki-laki & $29(58.0)$ & \\
\hline 3 & Jumlah Pasien Perempuan & $20(40.0)$ & $37.392(1.0801)$ \\
\hline \multirow{4}{*}{ Suhu ( ${ }^{\circ}$ C) pada MRS } & $49(98.0)$ & $3.31(1.917)$ \\
& Usia & $17(34.0)$ & \\
& O Bulan-5 Tahun & $2(4.0)$ & \\
4 & 6 Tahun-11 Tahun & $2(4.0)$ & \\
& 12 Tahun-17 Tahun & $12(24.0)$ & \\
& 41 Tahun-40 Tahun & $9(18.0)$ & \\
& Lebih dari 65 Tahun & $7(14.0)$ & \\
\hline \multirow{2}{*}{5} & Lama Rawat Inap & $35(70.0)$ & \\
& 2 Hari-7 Hari & &
\end{tabular}


Evaluasi Penggunaan Antibiotika Terhadap Pasien Pneumonia Komuniti Di Rumah Sakit Ibnu Sina Makassar

$\begin{array}{lc}8 \text { Hari-10 Hari } & 12(24.0) \\ 11 \text { Hari-13 Hari } & 1(2.0) \\ 14 \text { Hari-18 Hari } & 1(2.0)\end{array}$

Derajat celcius $\left({ }^{\circ} \mathrm{C}\right)$

Masuk Rumah Sakit (MRS)

Standard deviation (SD)

\section{Penggunaan Obat Berdasarkan Ketepatan Jenis Antibiotika}

Jenis antibiotik tunggal pasien pneumonia komuniti yang digunakan di RS. Ibnu Sina Makassar dapat dilihat pada tabel 2 sebagai berikut :

Tabel 2. Jenis antibiotik tunggal pasien pneumonia komuniti

\begin{tabular}{c|l|c}
\hline No & \multicolumn{1}{|c}{ Antibiotik } & Jumlah (\%) \\
\hline 1 & Azitromicin & $1(2,9)$ \\
2 & Cefixime & $5(14.7)$ \\
3 & Cefotaxime & $2(5,9)$ \\
4 & Ceftriaxone & $15(44,1)$ \\
5 & Cefadroxil & $2(5,9)$ \\
6 & Ceftazidime pentohidrate & $3(8,8)$ \\
7 & Cefditoren pivoxil & $1(2,9)$ \\
8 & Meropenem & $1(2,9)$ \\
9 & Levofloxacin & $2(5,9)$ \\
10 & Ciprofloxacin & $2(5.9)$ \\
\hline
\end{tabular}

Jenis antibiotik kombinasi pasien pneumonia komuniti yang digunakan di

RS. Ibnu Sina Makassar dapat dilihat pada tabel 3 sebagai berikut :

Tabel 3. Jenis antibiotik kombinasi pasien pneumonia komuniti

\begin{tabular}{c|l|c}
\hline No & \multicolumn{1}{|c|}{ Antibiotik } & Jumlah (\%) \\
\hline 1 & Cefixime dan levofloxacin & $1(4,8)$ \\
2 & Cefotaxime dan gentamisin & $12(57.1)$ \\
3 & Ampisilin dan gentamisin & $3(14.3)$ \\
4 & Azitromicin dan ceftazidime & $2(9,5)$ \\
5 & Ceftriaxone dan cefepime & $1(4,8)$ \\
6 & Ceftazidime dan levofloxacin & $1(4,8)$ \\
7 & Cefadroxil dan ceftriaxone & $1(4,8)$ \\
\hline
\end{tabular}

Pasien pneumonia komuniti dengan penggunaan antibiotika di RS. Ibnu Sina Makassar berdasarkan ketepatan jenis antibiotika dapat dilihat pada tabel 4 sebagai berikut :

Tabel 4. Ketepatan jenis antibiotika terhadap pasien pneumonia komuniti

\begin{tabular}{c|l|l|l}
\hline No & \multicolumn{1}{|c|}{ Pasien } & \multicolumn{1}{c}{ Kriteria } & \multicolumn{1}{c}{ Jumlah (\%) } \\
\hline 1 & Pasien Pneumonia komuniti & Tepat & $31(62.0)$ \\
& & Tidak Tepat & $18(38.0)$ \\
\hline \multicolumn{2}{c}{ Total } & $: 49(98)$
\end{tabular}


Evaluasi Penggunaan Antibiotika Terhadap Pasien Pneumonia Komuniti Di Rumah Sakit Ibnu Sina Makassar

\section{Penggunaan Obat Berdasarkan Ketepatan Dosis Antibiotika.}

Pasien pneumonia komuniti dengan penggunaan antibiotika di RS. Ibnu Sina Makassar berdasarkan Ketepatan dosis antibiotika dapat dilihat pada tabel 5 sebagai berikut :

Tabel 5. Ketepatan dosis antibiotika terhadap pasien pneumonia komuniti

\begin{tabular}{c|c|l|l}
\hline No & \multicolumn{1}{|c|}{ Pasien } & \multicolumn{1}{c}{ Kriteria } & \multicolumn{1}{c}{ Jumlah (\%) } \\
\hline 1 & Pasien Pneumonia komuniti & Tepat & $31(62.0)$ \\
& & Tidak Tepat & $18(38.0)$ \\
\hline \multicolumn{2}{r}{ Total } & $: 49(98)$
\end{tabular}

\section{Penggunaan Obat Berdasarkan Lama Pemberian Antibiotika.}

Pasien pneumonia komuniti dengan penggunaan antibiotika di RS. Ibnu Sina Makassar berdasarkan lama pemberian antibiotika dapat dilihat pada tabel 6 sebagai berikut :

Tabel 6. Lama pemberian antibiotika terhadap pasien pneumonia komuniti

\begin{tabular}{c|l|l|l}
\hline No & \multicolumn{1}{|c|}{ Pasien } & \multicolumn{1}{c}{ Kriteria } & \multicolumn{1}{c}{ Jumlah (\%) } \\
\hline 1 & Pasien Pneumonia komuniti & Tepat & $29(58.0)$ \\
& & Tidak Tepat & $20(40.0)$ \\
\hline \multicolumn{2}{r}{ Total } & $: 49(98)$
\end{tabular}

\section{PEMBAHASAN}

Penelitian ini adalah penelitian survei (non eksperimental) dengan metode deskriptif secara retrospektif terhadap evaluasi penggunaan antibiotika pada pasien pneumonia komuniti di RS. Ibnu Sina Makassar periode Januari sampai Desember 2013. Pengambilan sampel menggunakan metode purposive karena teknik pengambilan sampel secara sengaja dan sesuai dengan kriteria inklusi. Dari hasil penelitian yang dilakukan, diperoleh data-data yang mendukung pola penggunaan antibiotika pada pasien pneumonia komuniti. Pada pengolahan data selanjutnya, hanya sebanyak 50 pasien yang dirawat inap di RS. Ibnu Sina Makassar dengan diagnosa pneumonia komuniti yang termasuk kriteria inklusi namun hanya 49 pasien yang digunakan karena satu pasien di ekslusi karena data rekam medik pasien tersebut tidak lengkap.

Penelitian yang telah dilakukan dengan menggunakan 49 pasien yang akan diamati untuk tiga parameter yaitu ketepatan jenis antibiotik, ketepatan dosis antibiotik dan lama pemberian antibiotik berdasarkan tata laksana pneumonia komuniti oleh Infectious Diseases Society of America dan World Health Organization. 
Evaluasi Penggunaan Antibiotika Terhadap Pasien Pneumonia Komuniti Di Rumah Sakit Ibnu Sina Makassar

Pasien penderita pneumonia komuniti rawat inap di RS. Ibnu Sina Makassar terdapat 49 pasien yang terdiri dari pasien laki-laki dan perempuan. Evaluasi karakteristik pasien berdasarkan jenis kelamin dilakukan untuk mengetahui pengaruh jenis kelamin pada pasien pneumonia komuniti dirawat inap RS. Ibnu Sina Makassar. Pada distribusi frekuensi penderita pneumonia komuniti berdasarkan jenis kelamin jumlahnya tidak sama dari keseluruhan pasien yaitu 49 pasien, pasien laki-laki 29 (58.0\%) jumlahnya lebih banyak daripada pasien perempuan 20 (40.0\%). Hal ini disebabkan karena secara biologis sistem pertahanan tubuh laki-laki berbeda dengan perempuan dan pneumonia komuniti juga disebabkan karena laki-laki lebih sering beraktivitas diluar rumah dan lebih cenderung mengkonsumsi rokok, karena asap rokok mempunyai banyak zat kimia yang memicu terjadinya infeksi saluran pernapasan (Nugroho, 2011).

Umur pasien digunakan sebagai batasan dalam mengetahui banyaknya pasien penderita pneumonia komuniti dan pemberian dosis yang tepat pada pasien, sehingga antibiotik yang diberikan dapat memberikan efek yang optimal.
Pada kriteria pasien berdasarkan umur dibagi menjadi dua yaitu anak dan dewasa. Dari data yang diperoleh dari pasien pneumonia komuniti di RS. Ibnu Sina Makassar yaitu pada umur 0-5 tahun sebanyak 17 pasien (34.0\%), umur 6 tahun-11 tahun sebanyak 2 pasien (4.0\%), umur 12 tahun-17 tahun sebanyak 2 pasien (4.0\%), umur 18 tahun-40 tahun sebanyak 12 pasien (24.0\%), umur 41 tahun-65 tahun sebanyak 9 (18.0\%) dan umur lebih dari 65 tahun sebanyak 8 pasien (16.0\%). Pada pasien pneumonia komuniti kriteria yang paling banyak yaitu balita umur lebih 0 tahun-5 tahun. Hal ini disebabkan karena beberapa faktor yaitu gizi kurang, berat badan lahir rendah, tidak mendapatkan air susu ibu dan imunisasi yang memadai menyebabkan daya tahan tubuh terhadap penyakit infeksi menjadi kurang sehingga anak mudah terkena pneumonia komuniti dan juga karena kekebalan anak pada umur ini sangat rentan terhadap penyakit sehingga mudah terserang virus dan bakteri. Pada umur dewasa 18 tahun-40 tahun disebabkan karena orang dewasa yang rentan atau mudah terkena pneumonia komuniti salah satunya disebabkan oleh konsumsi rokok. Kebiasaan merokok mengubah bentuk 
Evaluasi Penggunaan Antibiotika Terhadap Pasien Pneumonia Komuniti Di Rumah Sakit Ibnu Sina Makassar

jaringan saluran napas dan fungsi

pneumonia komuniti ialah pembersih menghilang, saluran membengkak dan menyempit (Nugroho, 2011). Pada umur 41-65 tahun dan lebih dari 65 tahun disebabkan karena semakin tua umur pasien, maka ketahanan tubuh pada penyakit akan semakin rendah sehingga mudah terjangkit virus dan bakteri.

Pneumonia merupakan penyakit infeksi yang menyebabkan peradangan atau inflamasi parenkim paru yang biasanya berhubungan dengan pengisian cairan pada alveoli yang sebagian besar disebabkan oleh bakteri. Pengobatan pneumonia meggunakan antibiotik. Antibiotik yang digunakan pada pasien pneumonia komuniti dirawat inap RS. Ibnu Sina Makassar yaitu ampisilin, ceftriaxone, ciprofloxacin, cefepime, ceftazidime pentohidrate, cefotaxime, cefadroxil, cefditoren pivoxil, azitromicin, meropenem, gentamisin dan levofloxacin. Antibiotik tersebut merupakan golongan antibiotik dari golongan sefalosporin generasi I, II, III, dan IV, flurokuinolon, penisillin, makrolida dan aminoglikosida. Berdasarkan pedoman tata laksana Infectious Diseases Society of America pada pasien rawat inap non-ICU pengobatan antibiotik pasien rekomendasi pertama terapi tunggal flurokuinolon dan terapi kombinasi beta laktam (beta laktam meliputi cefotaxime, ceftriaxone dan ampisilin) dan makrolida.

Antibiotik mempunyai aktifitas spektrum sempit dan luas. Antibiotik spektrum yang luas aktif terhadap banyak spesies bakteri sedangkan antibiotik spektrum sempit hanya aktif terhadap satu atau beberapa bakteri. Antibiotik spektrum sempit seperti penisilin-G, eritromisin dan klindamisin hanya bekerja terhadap bakteri gram positif sedangkan streptomisin, gentamisin dan asam nalidiksat khusus aktif terhadap bakteri gram negatif. Antibiotik spektrum luas seperti sulfonamida, ampisilin dan sefalosporin bekerja terhadap lebih banyak bakteri gram positif maupun gram negatif.

Antibiotik yang merusak dinding sel mikroba dengan menghambat sintesis enzim atau inaktivasi enzim, sehingga menyebabkan hilangnya viabilitas dan sering menyebabkan sel lisis meliputi penisilin, sepalosporin. Antibiotik ini menghambat sintesis dinding sel terutama dengan mengganggu sintesis peptidoglikan. Ampisilin merupakan antibiotik golongan penisilin yang bersifat 
Evaluasi Penggunaan Antibiotika Terhadap Pasien Pneumonia Komuniti Di Rumah Sakit Ibnu Sina Makassar

bakterisida dan bekerja menghambat sintesis dinding sel. Antibiotik ini digunakan untuk pengobatan pneumonia karena spektrum kerjanya yang luas. Antibiotik yang menghambat sintesis protein sel mikroba ialah golongan aminoglikosida dan makrolida. Gentamisin merupakan golongan aminoglikosida yang digunakan secara luas untuk terapi infeksi serius dan gentamisin memiliki spektrum antibakteri yang luas. Antibiotik yang menghambat sintesis asam nukleat sel mikroba termasuk rifampisin dan kuinolon. Golongan kuinolon menghambat enzim DNA girase pada kuman. Ciprofloxacin merupakan golongan kuinolon yang aktif terhadap bakteri gram positif dan gram negatif.

Dari data yang diperoleh ketepatan jenis antibiotik dibandingkan dengan tata laksana pneumonia komuniti oleh Infectious Diseases Society of America dan World Health Organization, pasien dengan pengobatan yang tepat sebanyak 31 pasien $(62.0 \%)$, dan tidak tepat sebanyak 18 pasien (36\%). Penggunaan antibiotik yang tidak tepat disebabkan karena jenis antibiotik anak yang digunakan di RS. Ibnu Sina Makassar ialah terapi kombinasi golongan sefalosporin (cefotaxime) dan aminoglikosida (gentamisin) sedangkan menurut World Health Organization jenis antibiotik anak pada pasien pneumonia komuniti ialah rekomendasi pertama dengan ampisilin dan gentamisin dan rekomendasi kedua ialah ceftriaxone. Penggunaan terapi kombinasi antibiotik cefotaxime dan gentamisin dapat diberikan, penggunaan terapi tunggal antibiotik azitromicin dan penggunaan terapi kombinasi antibiotik cefixime dan levofloxacin dan kombinasi ceftazidime dan levofloxacin dianjurkan untuk pasien pneumonia namun tidak sesuai pada pedoman Infectious Diseases Society of America. Penggunaan antibiotik yang tidak sesuai atau tidak tepat dapat mengakibatkan hal-hal yang dapat merugikan pasien seperti meningkatnya jumlah bakteri yang resisten, timbulnya peningkatan efek samping dan toksisitas antibiotik, terjadinya pemborosan biaya, dan tidak tercapainya efek terapi dalam pencegahan maupun pengobatan infeksi.

Pada tata laksana pneumonia oleh Infectious Diseases Society of America menggunakan flurokuinolon sebagai terapi tunggal pada pasien pneumonia komuniti namun menurut Kathyn dan Woodhead (2007) 
Evaluasi Penggunaan Antibiotika Terhadap Pasien Pneumonia Komuniti Di Rumah Sakit Ibnu Sina Makassar

merekomendasikan golongan beta laktam digunakan sebagai terapi tunggal pada pasien pneumonia. Terapi antibiotik dianjurkan berbeda antara berbagai pedoman dan ini mungkin karena persepsi yang berbeda tentang pentingnya infeksi yang disebabkan oleh organisme atipikal, perbedaan resistensi antibiotik, perbedaan dalam penafsiran relevansi klinis resistensi antibiotik serta resistensi antibiotik. Resistensi Penisillin antara Streptococcus pneumoniae dengan tingkat $9,2 \%$ di Spanyol dan $15,9 \%$ pada USB. Resistensi di Inggris dan Belanda jauh lebih rendah ( 1,5 dan $0.5 \%$ ), sehingga mendukung penggunaan antibiotik beta laktam dan menurut Perhimpunan Dokter Paru Indonesia (2003), pasien pneumonia rawat inap menggunakan kombinasi golongan beta laktam dan anti betalaktamasi atau sefalosporin generasi II, III atau flurokuinolon.Salah satu penggunaan obat antibiotik yang di gunakan ceftriaxone (sefalosporin generasi kedua) dengan dosis bayi dan anak 50-75 mg/kg sekali sehari sedangkan pada dewasa $1 \mathrm{gr}$ sekali sehari selama 5-10 hari.

Ketidaktepatan dosis diklasifikasikan menjadi dua yaitu dosis tinggi dan dosis rendah. Pada kesesuain dosis antibiotik terhadap pasien pneumonia komuniti diperoleh pasien yang tepat sebanyak 31 pasien $(62 \%)$ dan tidak tepat sebanyak 18 (36\%). Ketidaksesuaian dosis terapi mungkin disebabkan karena pembulatan dosis baik melebihi maupun dibawah dosis seharusnya. Hal lain juga dapat menyebabkan ketidaksesuaian dosis berdasarkan berat badan adalah adanya penggelompokkan dosis berdasarkan umur tertentu. Ataupun dapat disebabkan karena perbedaan referensi yang digunakan antara peneliti dengan praktisi medis di RS. Ibnu Sina Makassar. Semakin tepat pemberian dosis, maka semakin cepat dan tepat pula tercapainya kadar antibiotika pada tempat infeksi, efek terapi yang optimal dipengaruhi oleh tercapainya kadar antimikroba pada tempat infeksi.

Pada evaluasi lama pemberian antibiotik di RS. Ibnu Sina Makassar dibandingkan dengan Infectious Diseases Society of America diperoleh data lama pemberian antibiotik tepat sebanyak 29 pasien (58.0\%) dan tidak tepat sebanyak 20 pasien $(40.0 \%)$. Apabila pemakaian antibiotik kurang dari waktu yang ditentukan akan terjadi kegagalan pengobatan, adanya bakteri resisten terhadap obat antibiotik tersebut, bahkan dapat lebih 
Evaluasi Penggunaan Antibiotika Terhadap Pasien Pneumonia Komuniti Di Rumah Sakit Ibnu Sina Makassar

berbahaya lagi terjadinya efek samping obat yang merugikan sehingga akan meningkatkan biaya yang mahal karena untuk penanggulangan dari efek pemakaian obat yang tidak sesuai aturan.

Pada kategori pasien berdasarkan lama rawat inap dari data yang didapatkan yaitu 2 hari-7 hari pasien dirawat inap sebanyak 35 pasien $(70.0 \%), 8$ hari-10 hari sebanyak 12 pasien (24.0\%), 11 hari13 hari sebanyak 1 pasien (2.0\%), 14 hari-18 hari sebanyak 1 pasien (2.0\%). Dari data yang didapatkan maka lama rawat inap paling banyak yaitu 2 hari-7 hari.

\section{KESIMPULAN}

Berdasarkan hasil penelitian yang dilakukan maka dapat disimpulkan sebagai berikut :

1. Ketepatan jenis antibiotika terhadap pasien pneumonia di RS. Ibnu Sina Makassar berdasarkan tata laksana pneumonia komuniti Infectious Diseases Society of America dan World Health Organization sebanyak 31 (62.0\%) pasien tepat dan sebanyak 18 (36.0\%) pasien tidak tepat.

2. Ketepatan dosis antibiotika pasien pneumonia di RS. Ibnu Sina Makassar berdasarkan tata laksana pneumonia komuniti
Infectious Diseases Society of America dan World Health Organization sebanyak 31 (62.0\%) pasien tepat dan sebanyak 18 (36.0\%) pasien tidak tepat.

3. Lama pemberian antibiotika pasien pneumonia di RS. Ibnu Sina Makassar berdasarkan tata laksana pneumonia komuniti Infectious Diseases Society of America dan World Health Organization sebanyak 29 (58.0\%) pasien tepat dan sebanyak 20 (40.0\%) pasien tidak tepat.

\section{DAFTAR PUSTAKA}

Amin, Alsagaf \& Saleh., 2003. Pengantar IImu Penyakit Paru. Surabaya: Airlangga University Press : 35-44.

Asih Retno S, dkk. 2006. Pneumonia. www.pediatrik.com. Diakses 3 Oktober 2013 .1-25.

Ambarwati Dewi Pramitya. 2011. Hubungan Karakteristik Anak dan Tingkat Pengetahuan Ibu Terhadap Kejadian Pneumosnia Pada Balita di Puskesmas Pencoran Mas.Jakarta .1-45.

Armitage, K and Woodhead, M. 2007. New Guidelines For The Management of Adult Community Acquired Pneumonia. Current Opinion in Infectious Diseases. 170-176.

Rizkianti Anissa.2009.Faktor - Faktor yang Berhubungan Dengan Kejadian Pneumonia Pada Balita 10-59 Bulan Yang Di Rawat Inap Di RSUP 
Evaluasi Penggunaan Antibiotika Terhadap Pasien Pneumonia Komuniti Di Rumah Sakit Ibnu Sina Makassar

Persahabatan Jakarta Tahun $2008.1-27$

Corwin, Elizabeth J. 2001. Buku Saku Patofisiologi. Alih Bahasa : Pendit, Brahm U. Jakarta : Penerbit Buku Kedokteran EGC.411-487.

Dongoes, Marlynn E. Frances, Mooerhoos $M$ \& Alice, Geissler.2000. Rencana Asuhan Keperawatan, Edisi III.Jakarta : Penerbit Buku Kedokteran EGC.164-175.

Dahlan Z. 2009. Pneumonia. Buku Ajar Ilmu Penyakit Dalam, Jilid II Edisi IV. Jakarta : Pusat Penerbitan Departemen IImu Penyakit Dalam FKUI. 21962206.

Departemen Kesehatan RI 2002 . Pedoman program pemberantasan penyakit infeksi saluran pernapasan akut (ISPA) untuk penanggulangan pneumonia pada balita. Jakarta: Depkes RI. 24-26.

Kakkilaya, Srinivas.2001.Rational Medicine: Rational use of antibiotics

www.rationalmedicine.org/antibi otics.htm. Diakses 3 Oktober 2013.1-17.

Lacy, C. F., Armstrong, L. L., Goldman, M. P., Lance, L. L., 2010. Drug Information Handbook. Lexi Comp : Nort America. 83-1451.

Misnadiarly .2008. Penyakit infeksi saluran nafas pneumonia pada anak, orang dewasa dan usia lanjut. Jakarta : Pustaka Obor populer.16-24.
Machmud, Rizanda.2006.Pneumonia Balita Di Indonesia dan Peranan Kabupaten dalam Menanggulanginya. Jakarta: Andalas University Press. 1322.

Mitrea, LS.2008. Pharmacology. Canada: Natural Medicine Books.

Mandell LA. Wunderink RG, Anzueto $A$, et al. 2007. Infectious Diseases Society of America/American Thoraric Society Consensus Guldelines On The management of Community Acquired Pneumonia in Adults. Clinical Infectious Diseases.27-72.

Neal, Michael J.2006. Medical Pharmacology At a Glance. Edisi 5. Penerbit Erlangga.

Nugroho Fendi, Utami, P.I., Yuniastuti, K. 2011. Evaluasi Penggunaan Antibiotik Pada Penyakit Pneumonia Di Rumah Sakit Umum Daerah Purbalingga, Pharmacy, 1 : 144-151.

Perhimpunan Dokter Paru Indonesia. 2003 . Pneumonia Komuniti. PDPI. Jakarta. 2-15.

Smeltzer, Suzanne C \& Bare, Brenda G. 2002 . Buku Ajar Keperawatan Medical-Bedah Brunner \& Suddarth, Edisi 8, Vol. 1. Alih Bahasa : Waluyo, A. Karyasa, I Made. Julia. Kuncara, H. Y \& Asih,Yasmin. Jakarta : Penerbit Buku Kedokteran EGC.57-60.

Stringer, Janet L. . 2006. Basic Concepts in Pharmacology: a Student's Survival Guide. Edisi 
Evaluasi Penggunaan Antibiotika Terhadap Pasien Pneumonia Komuniti Di Rumah Sakit Ibnu Sina Makassar

3. Jakarta: Buku Kedokteran EGC 186 - 199.

Negara berkembang. www.who.com. Diakses 3

Sharpe, B., Flanders, S. 2006. Community Acquired Pneumonia : A Practical Approach to Management For The Hospitalist. 1-14.

Suharjono., T,Yuniati., Sumarno dan SJ,Semedi. 2009. Studi Penggunaan Antibiotika Pada Penderita Rawat Inap Pneumonia (Penelitian Di Sub Departeman Anak Rumkital DR. Ramelan Surabaya), IImu Kefarmasian, 3 : 148-151.

Tait M.2004. Preparat antimikroba. Farmakologi kebidanan. Jakarta Oktober 2013.

WHO .2009. Pelayanan Kesehatan di Rumah Sakit. Jakarta : Depkes $\mathrm{RI}$.

WHO $2010.2 \quad$ Pneumonia .http://www.who.int/mediacentre /. Diakses 3 Oktober 2013.

World Health Organization. 2012. Recommendations For Management of Common Childhood Conditions: http://www.who.int/mediacentre/ factsheets/fs331/en/index. diakses 13 Februari 2014.

WHO .2003. Penanganan ISPA pada anak di rumah sakit kecil 